Int. J. Morphol.,

35(2):719-722, 2017

\title{
Anatomical Variations of the Foramen Transversarium in Cervical Vertebrae
}

\author{
Variaciones Anatómicas del Foramen Transverso en Vértebras Cervicales
}

\author{
Marcia Molinet Guerra ${ }^{1,2}$; Patricio Robles Fuentes ${ }^{2,3}$ \& Ignacio Roa Ig,5 $^{3,5}$
}

MOLINET, G. M.; ROBLES, F. P.; \& ROA, I. Anatomical variations of the foramen transversarium in cervical vertebrae. Int. J. Morphol., 35(2):719-722, 2017.

SUMMARY: The cervical vertebrae are recognized mainly by the presence of the foramen transversarium, which is crossed by the vertebral artery and vein, accompanied by sympathetic fibers. The main objective of this study was to observe and describe the anatomy and variations in the foramen transversarium. 121 cervical vertebrae were analyzed, including the macroscopic characteristics, shape and diameter and presence of the foramen transversarium, as well as the accessory foramen transversarium. All cervical vertebrae presented the foramen transversarium, with a mean diameter of $5.60 \mathrm{~mm}$ and a mean diameter of $4.40 \mathrm{~mm}$ on the right and $5.92 \mathrm{~mm}$ $5.56 \mathrm{~mm}$ on the left, respectively. With regard to shape classification according to Taitz et al. (1978), $90.08 \%$ presented the same shape on both sides, and $9.91 \%$ had different shapes. The presentation of the different shapes was as follows: shape $141.32 \%$; shape $24.13 \%$; shape $318.8 \%$; shape $414.04 \%$; and shape $512.39 \%$. Regarding the presence of accessory foramen transversarium, $17.35 \%$ of the vertebrae presented it, $66.6 \%$ unilateral, $57.14 \%$ on the right side and $42.85 \%$ on the left side. Osteophytes, were presented in $5.7 \%$. The anatomical knowledge of these variations is useful for spine surgeons in preoperative planning and for preventing vertebral vessel and sympathetic nerve injuries during cervical surgical approaches.

KEY WORDS: Cervical vertebra; Foramen transversarium; Accessory foramen; Vertebral artery.

\section{INTRODUCTION}

The cervical vertebrae are mainly recognized by the presence of the foramen transversarium (FT), located in the transverse process and inside it the course the vertebral artery and vein, accompained by the simpathetic plexus (SanchisGimeno et al., 2005). The variations are mainly associated with the width and path of the vascular elements (Das et al., 2005), and this may cause alterations like vertebrobasilar insufficiency (Kaya et al., 2011), or modify the blood flow, due to a strong link between the diameter of the FT and the blood flow of the vertebral artery (Kotil \& Kilincer, 2014).

The anatomical details in the FT variations are important for physicians, and radiologist in the interpretation of the medical images (Murlimanju et al., 2011). This importance is that the lesions in both the FT and the vertebral artery may be produced by penetrating injuries, trauma lesions, and overall after vascular compression secondary to fractures or luxations (Dalgic et al., 2009).
It is possible to observe the presence of abnormal bony outgrowths (ostephytes) inside the FT, which theoretically can produce lesions to the vertebral artery, vein, and the sympathetic plexus (Strek et al., 1998). The external pressure generated by the degenerative changes in the cervical spine, can produce compressión of the vertebral artery (Cockerill et al., 2000).

The aim of this study is to ascertain the incidence of the alterations of the FT in the cervical vertebrae, analyze then mophologically emphasizing in its surgical and clinical relevance.

\section{MATERIAL AND METHOD}

One hundred and twenty-one cervical vertebrae from a Chilean population were obtained from the Department of

\footnotetext{
1 Escuela de Tecnología Médica, Universidad Austral de Chile, Sede Puerto Montt, Chile.

2 Programa de Magister en Ciencias Morfológicas, Facultad de Medicina, Universidad de La Frontera, Temuco, Chile.

3 Unidad de Morfología, Departamento de Ciencias Básicas Biomédicas, Facultad de Ciencias de la Salud, Universidad de Talca, Chile.

${ }^{4}$ Programa de Doctorado en Ciencias Morfológicas, Facultad de Medicina, Universidad de La Frontera, Temuco, Chile.

5 Becario CONICYT-PCHA/Doctorado Nacional/2015-21150235.
} 
Basic Biomedical Sciences of the Universidad de Talca, Chile. All of the vertebrae included were in good condition, with no signs of trauma, infectious or neoplastic diseases, and with no apparent deformities. All measurements were bilaterally conducted by three independent observers using a digital Vernier caliper (Fowler Sylvac) to an accuracy of $0.01 \mathrm{~mm}$ precision. The sex and age of the bones are unknown. For the analysis, every vertebra was indentified and numbered.

The FT were observed macroscopically in each vertebra on both sides, as well as the presence of the accesory foramen transversarium (AFT). The maximum and minimum diameters of the FT were measured bilaterally using a digital caliper. We also studied the presence of ostephytes in the unciform process. The FT shape was recorded according to the parameters of Taitz et al. (1978).

\section{RESULTS}

A total of 121 cervical vertebrae were analyzed, 30 for each level (C3, C4, C5, C6, C7). Of the 121 cervical vertebrae, all presented $\mathrm{FT}$ with a mean maximum and minimum diameter media of $5.60 \mathrm{~mm}$ and $4.40 \mathrm{~mm}$ on the right side respectively, and $5.92 \mathrm{~mm}$ and $5.57 \mathrm{~mm}$ on the left side. The values by segment are shown in Table I.

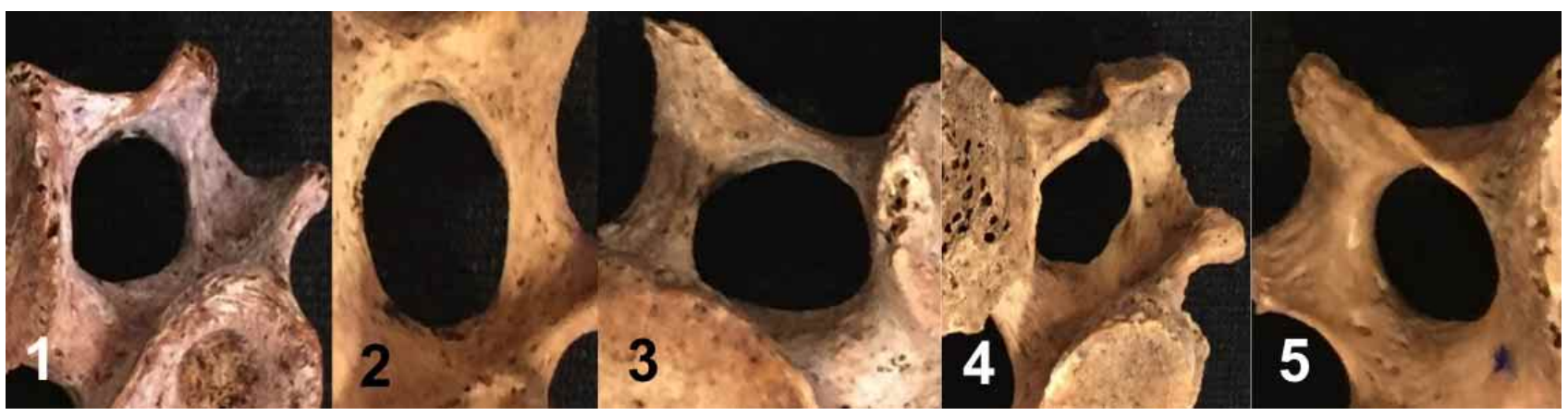

Fig. 1. Classification of the foramen transversarium according to Taitz et al., 1978.

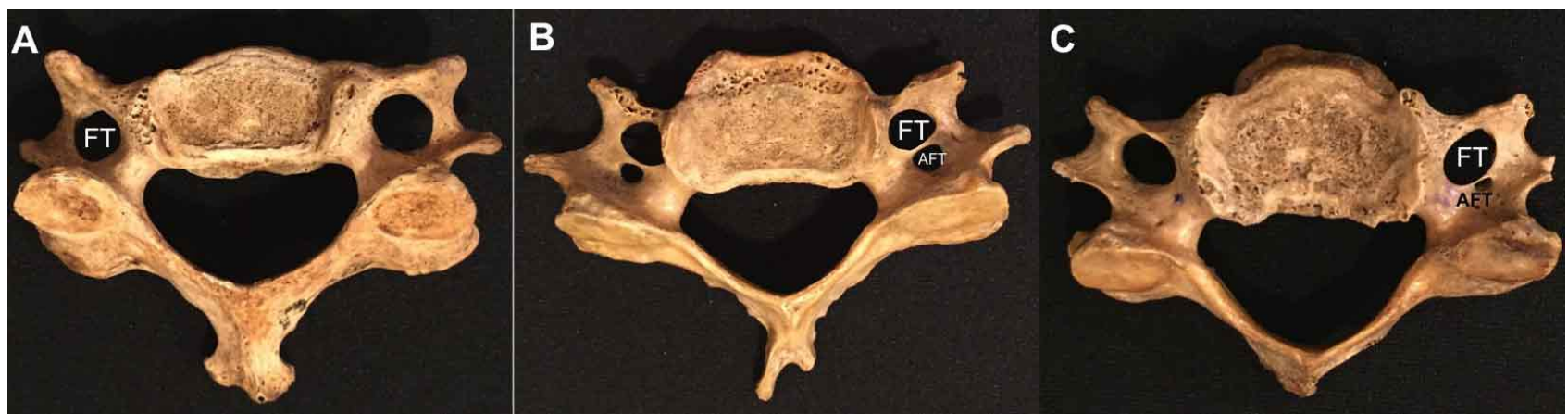

Fig. 2. Cervical vertebrae. A. Foramen transversarium (FT). B. Bilateral accessory foramen transversarium (AFT). C. Unilateral accessory foramen transversarium.

Table I. Cervical vertebrae characteristics. Maximum left (Max. left); Minimum left (Min. left) diameters; Maximum right (Max. right) and minimum right (Min. right) of the vertebrae. Shape as described by Taitz et al. (1978). The mixed (mix) classification corresponds to the vertebrae presented differently to the right and left. The presence of osteophytes (OST) and accessory foramen transversarium (AFT).

\begin{tabular}{|c|c|c|c|c|c|c|c|c|c|c|c|c|c|}
\hline \multirow{2}{*}{$\begin{array}{l}\text { Cervical } \\
\text { vertebrae }\end{array}$} & \multirow[b]{2}{*}{$\mathbf{n}$} & \multicolumn{4}{|c|}{ Diameter (mm) } & \multicolumn{6}{|c|}{ Shape (\%) } & \multirow{2}{*}{$\begin{array}{l}\text { OST } \\
(\%)\end{array}$} & \multirow[t]{2}{*}{ AFT (\%) } \\
\hline & & $\begin{array}{l}\text { Max. } \\
\text { Left }\end{array}$ & $\begin{array}{l}\text { Min. } \\
\text { Left }\end{array}$ & $\begin{array}{l}\text { Max. } \\
\text { Right }\end{array}$ & $\begin{array}{l}\text { Min. } \\
\text { Righ }\end{array}$ & 1 & 2 & 3 & 4 & 5 & Mix & & \\
\hline C1 & 25 & 7.01 & 5.51 & 6.63 & 4.98 & 20 & 20 & 0 & 24 & 24 & 12 & $1(4)$ & $4(16)$ \\
\hline $\mathrm{C2}$ & 22 & 8.82 & 4.53 & 6.11 & 4.78 & 68 & 0 & 4.5 & 0 & 22 & 0 & $0(0)$ & $0(0)$ \\
\hline C3-C6 & 64 & 5.29 & 4.43 & 6.11 & 5.15 & 43.7 & 0 & 32 & 15.6 & 3.1 & 7.8 & $5(7.8)$ & $15(23.4)$ \\
\hline C7 & 9 & 5.42 & 4.72 & 5.3 & 4.47 & 33.3 & 0 & 0 & 11.1 & 11.1 & 4.8 & $1(11.1)$ & $2(22.2)$ \\
\hline Total & 121 & & & & & 41.3 & 4.1 & 18.8 & 14 & 12.3 & & 5.7 & 17.35 \\
\hline
\end{tabular}


Using the shape classification by Taitz et al., 90.08 $\%$ presented the same shape bilaterally, and in a $9.91 \%$ in differents shapes. The presentation of distinct shapes is as it follows: shape $141.32 \%$; shape $24.13 \%$; shape $318.8 \%$; shape $414.04 \%$; shape $512.39 \%$ (Fig. 1).

With regard to the presence of AFT, $17.35 \%$ of the vertebrae presented it, being a $66.6 \%$ unilaterally, $57.14 \%$ on the right side and $42.85 \%$ on the left (Fig. 2).

\section{DISCUSSION}

In the past, various authors have conducted many studies regarding the variations in number, size and shape of the FT. The AFT is a low-frecuency anatomical variation, and it may therefore be possible to predict the modification in the course and in the pattern of the vertebral artery, vertebral vein and sympathetic nerves inside the FT (Aydinogly et al., 2001), and it is also possible to find a duplicated vertebral artery (Taitz et al.).

With respect to the shape and diameter of the FT, Sangari et al. (2015), found the mean diameter of the right and left FT varied from $2.54 \mathrm{~mm}$ to $7,79 \mathrm{~mm}$ (mean: $5.55 \pm$ $0.87 \mathrm{~mm}$ ) and from $2.65 \mathrm{~mm}$ to $7.35 \mathrm{~mm}$ (mean: $5.48 \pm 0.77$ $\mathrm{mm}$ ) respectively. These values are different from our results. In our study, we categorized the shape of the FT according to the criteria by Taitz et al. We found that most of the foramina on the right and left sides had shape 1 . This contrasts with the work done by other authors that shape 4 was predominant (40.2\%), on the right side, while shapes 2 and 5 were predominant (39.2\% each) on the left (Karau \& Odula, 2012).

By contrast, the presence of the AFT, has been previously reported (Taitz et al.; Aydinoglu et al., 2001; Murlimanju et al.; Das et al.; Sharma et al., 2010; Chandravadiya et al., 2013; Rathnakar et al., 2013; Agrawal et al., 2012; Murugan \& Verma, 2014), in different populations with distinct results. Aydinoglu et al. (2011) in his study, after observing 222 cervical vertebrae, reported a frequency of 6.7 $\%$ of the AFT on both sides; meanwhile, Das et al. and Kaya et al. reported values of $1.5 \%$ and $22.7 \%$ respectively. Agrawal et al. reported the presence of a bilateral ATF in $1.25 \%$, and unilateral in $2.5 \%$ from a total of 160 typical cervical vertebrae. Conversely, Katikieddi \& Setty (2014) studied 100 cervical vertebrae, and reported the presence of AFT in 3\%, with $2 \%$ and $1 \%$ located unilaterally and bilaterally respectively. Other authors report double FT in $22.00 \%$ vertebrae, among which double foramen were observed unilaterally in $10.67 \%$ vertebrae and bilaterally in $11.33 \%$ vertebrae (Patra et al., 2015).
Meanwhile, in the present study, we observed the AFT in $17.35 \%$ of the cases. These data are similar to the results reported by Murugan \& Verma, who observed 150 cervical vertebrae, finding $12.6 \%$ of the vertebrae with an AFT, and Mishra et al. (2014), who reported $14.09 \%$ cases from a total of 220 dry typical (C3-C6) cervical vertebrae from both sexes. The C3-C6 segment had a higher frecuency of AFT, with a $23,4 \%$, similar to the results of El Shaarawy et al., who observed the incidence of AFT as being more common in the lower cervical spine (C5, C6 and C7). Regarding the locations of the AFT, in our study we observed a higher unilateral presentation, consistent with the findings of other authors (Agrawal et al.; Chandravadiya et al.; Chaudhari et al., 2013; Katikireddi \& Setty).

Osteophytes were present in $5.7 \%$ of the vertebrae, presenting mostly in the $\mathrm{C} 7$ segment, much lower than those reported by Sanchis-Gimeno et al. (2005), which indicate that the C6 segment is the most prevalent (39.28\%), at $15 \%$ of the vertebrates analyzed $(n=560)$.

The embryological development of the vertebral artery, the main content of the FT, may be closely related to the presence of these variations. The vertebral artery develops from the fusion of the longitudinal anastomosis that joins the cervical intersegmentary arteries, which branches from the primitive dorsal aorta (Ionete \& Omojola, 2006). The duplication of the vertebral artery, is thought to represent the failure of the controlled regression of two intersegmentary arteries, and a segment of the primitive dorsal aorta. Further, developmental changes could account for the variations observed. Previous authors have cited stress and posture in the erect human as factors responsible for shaping the bony architecture of the neck region (Taitz \& Nathan, 1986).

The morphological knowledge of this variation type is clinically important in many ways, due to the modifications that can be present in the vertebral artery pathway. The compression of the vertebral artery can produce neurological symptoms, such as headache, migraine, fainting and auditive disorders. Either way, it is crucial to knowing the alterations of the FT, particulary for the surgeons and neurosurgeons, prior to a posterior cervical surgery. Fort he radiologist, the importance lies on the interpretation of the medical images, such as computed tomography (CT scan), magnetic resonance imaging (MRI), and the right presentation of informs. Our study provides more information about the incidence and morphological characteristics of the FT.

In conclusion, despite of the difference in results in the studies corresponding to the FT, in terms of sample, sex and segments to be analyzed, this report provides additional information about the incidence and morphology of the FT 
and it's variations. The presence of an AFT in all the vertebrae was of $17.35 \%$, with the C3-C6 segment having the highest incidence $(23.4 \%)$. The unilateral presentation is the most common. The morphological knowledge is clinically and surgically important, given that the course of the vertebral artery may be disturbed in such situations. Further studies about this topic can be correlated with the data found in medical images and clinical histories or patients symptoms.

MOLINET, G. M.; ROBLES, F. P. \& ROA, I. Variaciones anatómicas del foramen transverso en vértebras cervicales. Int. J. Morphol., 35(2):719-722, 2017.

RESUMEN: Las vértebras cervicales son reconocidas principalmente por la presencia del foramen transverso (FT), por el cual transita la arteria y vena vertebral además de fibras simpáticas. Las variaciones en el FT pueden estar asociadas con una alteración en el calibre y el curso de la arteria vertebral. El objetivo del presente estudio fue observar y describir la anatomía así como las variaciones en el FT. Fueron analizadas 121 vértebras cervicales, en las cuales el FT fue observado macroscópicamente de manera bilateral así como el foramen transverso accesorio (FTA) en las que se encontrara presente. La forma y diámetros máximo y mínimo del FT fue medido de manera bilateral con ayuda de un cáliper digital. De 121 vértebras cervicales, la totalidad presentaron FT con diámetros máximo y mínimo derecho de 5,60 y 4,40 mm respectivamente y de 5,92 y $5,56 \mathrm{~mm}$ máximo y mínimo del lado izquierdo. Con respecto a la clasificación de forma de Taitz et al. (1978) el 90,08 \% presentó la misma forma de manera bilateral y un $9,91 \%$ formas distintas. La forma 1 se presentó en un $41,32 \%$, la 2 en un 4,13\%, forma 3 $18,8 \%, 414,04 \%$ y 5 en $12,39 \%$. Con respecto a la presencia de FTA, un $17,35 \%$ lo presentó, siendo $66,6 \%$ unilaterales, un $57,14 \%$ derecho y $42,85 \%$ izquierdo. La anatomía y variaciones en el FT y la arteria vertebral y los componentes nerviosos están interrelacionados. Su conocimiento morfológico es clínicamente importante, ya que el curso de la arteria vertebral puede distorsionarse en tales situaciones. Por lo que es importante a la hora de adoptar medidas cautelares para salvaguardar la arteria vertebral en las cirugías de columna cervical.

PALABRAS CLAVE: Vértebra cervical; Foramen transverso; Foramen accessorio; Arteria vertebral.

\section{REFERENCES}

Agrawal, D.; Mohanty, B. B.; Sethy, S.; Parija, B.; Hazary, S. K. \& Chinara, P. K. Variations in foramen transversarium: an osteological study in Eastern India. Int. J. Current Research, 4(9):120-2, 2012.

Aydinoglu, A.; Kavakli, A.; Yesilyurt, H.; Erdem S. \& Eroglu, C. Foramen transversarium bipartita. Van Tip Dirgisi, 8(4):110-112, 2001.

Chandravadiya, L.; Shailesh, P.; Goda, J.; Chavda, V.; Ruparelia, S. \& Shamin, P. Double foramen transversarium in cervical vertebra: morphology and clinical importance. Int. J. Res. Med., 2(1):103-5, 2013.

Chaudhari, M. L. Maheria, P. B. \& Bachuwar, S. P. Double foramen transversarium in cervical vertebra: Morphology and clinical importance. IJBAMR, 2:1084-8, 2013.

Cockerill, W.; Ismail, A. A.; Cooper, C.; Matthis, C.; Raspe, H.; Silman, A. J. $\&$ O'Neill, T. W. Does location of vertebral deformity within the spine influence back pain and disability? European Vertebral Osteoporosis Study (EVOS) Group. Ann. Rheum. Dis., 59(5):368-71, 2000.

Dalgic, A.; Okay, O.; Nacar, O.; Daglioglu, E.; Pasaoglu, L. \& Belen, D. Vertebral artery insult at the transverse foramina by gun shot wounds: report of two cases. Turk. Neurosurg., 19(4):413-6, 2009
Das, S.; Suri, R. \& Kapur, V. Double foramen transversaria. An osteological study with clinical implications. Int. Med. J., 12(4):311-3, 2005.

El Shaarawy, E. A.; Sabry, S. M.; El Gammaroy, T. \& Nasr, L. Morphology and morphometry of the foramina transversaria of cervical vertebrae: A correlation with the position of the vertebral artery. Kasr El Aini Medical Journal, 10, 2010.

Ionete, C. \& Omojola, M. F. Angiographic demonstration of bilateral duplication of extra cranial vertebral artery unusal course and review of literature. AJNR Am. J. Neuroradiol., 27(6):1304-6, 2006.

Katikireddi, R. S. \& Setty, S. N. A study of double foramen transversarium in dried cervical vertebra. Int. J. Health Sci. Res, 4(1):59-61, 2014.

Karau, P. B. \& Odula, P. Some anatomical and morphometric observations in the transverse foramina of the atlas among Kenyans. Anat. J. Afr., 2(1):616, 2013.

Kaya, S.; Yilmaz, N. D.; Pusat, S.; Kural, C.; Kirik, A. \& Izci, Y. Double foramen transversarium variation in ancient Byzantine cervical vertebrae: Preliminary report of an anthropological study. Turk. Neurosurg., 21(4):534-8, 2011

Kotil, K. \& Kilincer, C. Sizes of the transverse foramina correlate with blood flow and dominance of vertebral arteries. Spine J., 14(6):933-7, 2014.

Mishra, G. P.; Bhatnagar, S.; Singh, B.; Mishra, P. P. \& Mishra, A. Anatomical variations in foramen transversarium of typical cervical vertebrae and clinical significance. Int. J. of Biomed. Res., 5(6):405-7, 2014.

Murlimanju, B. V.; Prabhu, L. V. Shilpa, K.; Rai, R.; Dhananjaya, K. V. \& Jiji, P. J. Accessory transverse foramina in the cervical spine: Incidence, embryological basis, morphology and surgical importance. Turk. Neurosurg., 21(3):384-7, 2011.

Murugan, M. \& Verma, S. A study on variations of foramen transversarium of cervical vertebrae. National Journal of Clinical Anatomy, 3(1):4-7, 2014.

Patra, A.; Kaur, H.; Chhabra, U.; Kaushal, S. \& Kumar, U. Double foramen transversarium in dried cervical vertebra: An osteological study with its clinical implications. Indian J. Oral Sci., 6(1):7-9, 2015.

Rathnakar, P.; Remya, K. \& Swathi. Study of accessory foramen transversaria in cervical vertebrae. Nitte University Journal of Health Science, 3(4):979, 2013.

Sanchis-Gimeno, J. A.; Martínez-Soriano, F. \& Aparicio-Bellver, L. Degenerative anatomic deformities in the foramen transversarium of cadaveric cervical vertebrae. Osteoporos. Internat., 16(9):1171-2, 2005.

Sangari, S. K.; Dossous, P-M.; Heineman, T. \& Mtui, E. P. Dimensions and anatomical variants of the foramen transversarium of typical cervical vertebrae. Anat. Res. Int., 2015, 2015. http://dx.doi.org/10.1155/2015/ 391823

Sharma, A.; Kuldeep, S.; Gupta, V. \& Srivastava, S. Double foramen transversarium in cervical vertebra an osteological study. J. Anat. Soc. India, 59(2):229-31, 2010.

Strek, P.; Reron, E.; Maga, P.; Modrzejewski, M. \& Szybist, N. A possible correlation between vertebral artery insufficiency and degenerative changes in the cervical spine. Eur. Arch. Otorhinolaryngol., 255(9):43740, 1998.

Taitz, C.; Nathan, H. \& Arensburg, B. Anatomical observations of the foramina transversaria. J. Neurol. Neurosurg. Psychiatry, 41(2):170-6, 1978.

Taitz, C. \& Nathan, H. Some observations on the posterior and lateral bridge of the atlas. Acta Anat. (Basel), 127(3):212-7, 1986.

Corresponding author:

Dr. Ignacio Roa Henríquez

Unidad de Morfología

Departamento de Ciencias Básicas Biomédicas

Facultad de Ciencias de la Salud

Universidad de Talca Av. Lircay s/n

Talca - CHILE

E-mail: iroa@utalca.cl

Received: 11-01-2017

Accepted: 24-02-1017 